\title{
Business analysis of factors and conditions for the development of sugar production organizations
}

\author{
Oksana Pirogova ${ }^{1},{ }^{*}$ Roman Nuzhdin ${ }^{2}$, and Boris Pivovar ${ }^{3}$ \\ ${ }^{1}$ Peter the Great St. Petersburg Polytechnic University, 195251, 29 Polytechnicheskaya str., St. \\ Petersburg, Russia \\ ${ }^{2}$ Voronezh State University of Engineering Technologies, 394036, 19 prospekt Revolyucii, \\ Voronezh, Russia \\ ${ }^{3}$ The Russian Presidential Academy of National Economy and Public Administration, 119571, 84, \\ bldg 2, Prospect Vernadskogo, Moscow, Russia
}

\begin{abstract}
The purpose of this study is, using the example of sugar production, to identify parametric characteristics and relationships that make it possible to simulate an algorithm and assessment procedures for predicting the possible results of the economic activity of processing organizations in the context of unstable business relations with suppliers of beet raw materials. The developed methodological approach is based on the classification of factors and conditions by sources of occurrence (external, conjugate and internal environment). When modeling scenario and situational changes, the assumptions inherent in the law of "diminishing returns" were made. In particular, only units of the conjugate environment (beet losses during storage and transportation; sugar losses during storage and in production; conjugation coefficient) are presented as dynamic (subject to change) indicators, the rest are positioned as constants, justifiably unchanged in the short term. Approbation of the proposed valuation procedures made it possible to identify imbalances in the level of dynamics of the resulting indicators (specific profit from sales (per ton of product) and profitability of sales with deviations in the values of the conjugation coefficient of the relative base level characterizing the balance of business relations with suppliers. Based on the results obtained, a conclusion was made about the possibility of manifestation of the established disproportions and the effective use of the proposed methodological approach for their leveling in the subjects of other industries.
\end{abstract}

\section{Introduction}

The development of economic activity of organizations of sugar production in Russia is undergo-ing significant changes initiated by the influence of diverse and ambiguously

\footnotetext{
* Corresponding author: kafedra17@,rambler.ru
} 
influencing factors of the external, associated and internal business environment [1]. Having mainly a socio-economic na-ture, the named factors are interdependent and interrelated in the closest and most diverse way [2]. The reciprocal influence of factors, first, is expressed in the polarity of influence, and based on the dual effect of synergy forms both positive and negative conditions for conducting economic activity, and, accordingly, the possibility of developing sugar production. The development of the economic activity of sugar factories is associated with the constant search and mobilization of unused opportunities of the available resource potential, as well as the system of business relations. Therefore, it becomes nec-essary to update the management tools of organizational development, first of all, based on the knowledge of environmental factors [3], which are the reason for the formation of conditions that impede the development of economic activity of processing organizations of sugar production.

When assessing the possibilities of conjugating the interests of participants in business processes in sugar production, it is necessary, first, to identify the key factors, the structure and interrelation of which affects the result - profit per ton of sugar. We have classified the types of factors and conditions that affect the results of the development of the economic activity of sugar factories, and have classi-fied the key environmental factors that prevent favorable conditions for the development of sugar pro-duction (Table 1). During the assessment of the identified factors, the special status of the factors of the associated environment was established - the nature and content of business relations with produc-ers of beet raw materials and beet seeds, which determine the qualitative parameters of the business process "harvesting beet raw materials".

Table 1. Key factors and environmental conditions that hinder the development of economic activity of sugar production organizations.

\begin{tabular}{|c|c|c|}
\hline $\begin{array}{l}\text { Envi } \\
\text { Ron } \\
\text { ment }\end{array}$ & Factors & Conditions \\
\hline \begin{tabular}{|l|}
1 \\
\end{tabular} & 2 & 3 \\
\hline \multirow{10}{*}{ 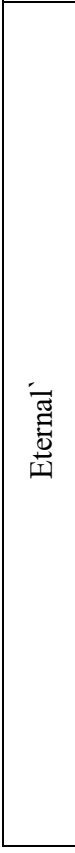 } & \multirow{4}{*}{ 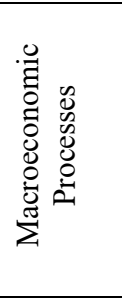 } & $\begin{array}{l}\text { The sugar market of the CIS countries is under pressure from imports from third } \\
\text { countries }\end{array}$ \\
\hline & & $\begin{array}{l}\text { Introduction of financial and economic sanctions against Russia by a number of } \\
\text { foreign countries }\end{array}$ \\
\hline & & $\begin{array}{l}\text { Negative dynamics of national currencies against the dollar and euro, leading to } \\
\text { an increase in the cost of sugar in the national currency }\end{array}$ \\
\hline & & $\begin{array}{l}\text { The global sugar balance is in surplus and is under pressure from accumulated } \\
\text { excess stocks }\end{array}$ \\
\hline & \multirow{2}{*}{ 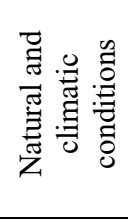 } & $\begin{array}{l}\text { Climate change leads to an increase in temperature, precipitation and, as a } \\
\text { consequence, the volume of harvesting of sugar beets, sugar supply on the } \\
\text { market, changes in prices and incomes of beet and sugar producers }\end{array}$ \\
\hline & & $\begin{array}{l}\text { Climatic conditions unpredictably affect the yield of beets and their quality } \\
\text { characteristics, the length of the season, the use of production capacity and } \\
\text { production costs }\end{array}$ \\
\hline & \multirow{4}{*}{ 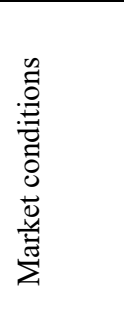 } & $\begin{array}{l}\text { Population incomes grow at a slower pace than prices for goods and services, } \\
\text { which limits consumer demand }\end{array}$ \\
\hline & & $\begin{array}{l}\text { The existence of a surplus of sugar in the world is combined with uneven } \\
\text { demand }\end{array}$ \\
\hline & & $\begin{array}{l}\text { Low wholesale prices for beet sugar that persist for a long time with a constant } \\
\text { increase in prices for fuels and lubricants, fertilizers, plant protection products, } \\
\text { equipment and other resources, reduce the profitability of sugar production }\end{array}$ \\
\hline & & $\begin{array}{l}\text { Decrease in sugar consumption in Russia due to increased competition from } \\
\text { manufacturers of sugar substitutes }\end{array}$ \\
\hline
\end{tabular}




\begin{tabular}{|c|c|c|}
\hline & & $\begin{array}{l}\text { In the context of tougher sanctions, restrictions on the supply of seed material } \\
\text { and changes in its price environment may arise, which in the next production } \\
\text { cycle will cause an increase in prices on the market for its processed products }\end{array}$ \\
\hline & & $\begin{array}{l}\text { Exceeding the optimal load on one unit of beet-harvesting equipment, } \\
\text { insufficient provision of farms with combines and unsatisfactory condition of } \\
\text { their material and technical base }\end{array}$ \\
\hline & & Imperfect organization of field cagation processes \\
\hline & & $\begin{array}{l}\text { Low level of application of resource-saving technologies and the use of seed } \\
\text { material of regionalized hybrids adapted to stress factors of beet-growing } \\
\text { regions of the country }\end{array}$ \\
\hline & & Early harvest of sugar beets due to lack of processing capacity \\
\hline & $\frac{?}{\stackrel{\overbrace{}}{0}}$ & $\begin{array}{l}\text { The use of imported seeds that are not adapted to the conditions of reproduction } \\
\text { in Russian climatic conditions does not bring the expected results }\end{array}$ \\
\hline & 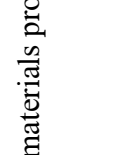 & $\begin{array}{l}\text { Causes of sugar beet losses: suboptimal setting of equipment during harvesting } \\
\text { (combines, loaders), non-compliance with technical standards during storage in } \\
\text { the field, suboptimal planning of the digging sequence, volumes of } \\
\text { transportation to the plant }\end{array}$ \\
\hline & $\underset{\pi}{2}$ & $\begin{array}{l}\text { Due to the lack of working capital, mineral fertilizers are not applied at the } \\
\text { optimal time (August, September) or are used in an incomplete volume }\end{array}$ \\
\hline & & $\begin{array}{l}\text { The lack of clear motivation of farms does not give them the opportunity to } \\
\text { conclude insurance contracts, therefore they depend on natural disasters, the } \\
\text { dishonesty of sellers and manufacturers of products necessary for growing crops }\end{array}$ \\
\hline & & $\begin{array}{l}\text { When harvesting, errors occur that cannot be corrected - non-compliance with } \\
\text { the row spacing, uneven fields }\end{array}$ \\
\hline & & $\begin{array}{l}\text { Insufficient attention is paid to the pre-harvesting maintenance of beet crops, } \\
\text { sorting them by quality and shelf life }\end{array}$ \\
\hline & $\sum_{\infty}^{\infty}$ & $\begin{array}{l}\text { The mismatch between the economic interests of beet-growing farms and sugar } \\
\text { factories, contributing to the reduction of material and technical and labor } \\
\text { resources and undermining food security }\end{array}$ \\
\hline & 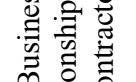 & $\begin{array}{l}\text { The imbalance in the production and processing of raw beets is explained by the } \\
\text { divergence of interests of the participants in sugar production }\end{array}$ \\
\hline 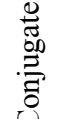 & 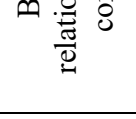 & $\begin{array}{l}\text { Refusal of sugar factories to accept raw materials from third-party beet-growing } \\
\text { farms at beet-receiving points; the requirement to store beets in field piles, then } \\
\text { supply them to the plant according to an insufficiently agreed schedule }\end{array}$ \\
\hline & 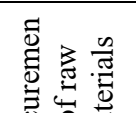 & $\begin{array}{l}\text { The lack of beet-receiving points equipped with modern high-performance } \\
\text { handling equipment, low keeping quality of sugar beet reduces the weight and } \\
\text { quality of root crops, which leads to an increase in the loss of beet raw materials }\end{array}$ \\
\hline & 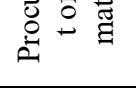 & $\begin{array}{l}\text { The direction of development of beet processing "off wheels", which was } \\
\text { wrongly chosen by Russian producers }\end{array}$ \\
\hline & $\underset{\mathscr{\Xi}}{\mathscr{\Xi}}$ & $\begin{array}{l}\text { Reduction of production capacity due to the withdrawal of capacity for } \\
\text { reconstruction, violation of the optimal structure of crops, leading to an } \\
\text { unreasonable increase in the cost of transporting raw materials }\end{array}$ \\
\hline & 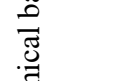 & $\begin{array}{l}\text { Lack of production capacity complicating the production process and increasing } \\
\text { the cost of sugar production }\end{array}$ \\
\hline 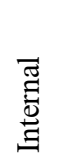 & 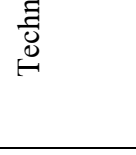 & $\begin{array}{l}\text { Raw materials laboratories do not have the ability to quickly check the } \\
\text { correctness of the results obtained on automated lines, so they are assigned to the } \\
\text { central plant laboratories, where discrepancies arise in the results of determining } \\
\text { the sugar content }\end{array}$ \\
\hline & 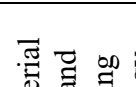 & $\begin{array}{l}\text { Diffusion-evaporated, limestone-carbon dioxide technology for sugar production } \\
\text { is becoming obsolete }\end{array}$ \\
\hline & 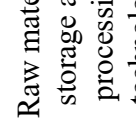 & In raw materials laboratories, physically and morally obsolete equipment is used \\
\hline
\end{tabular}




\begin{tabular}{|c|c|}
\hline \multirow{2}{*}{ 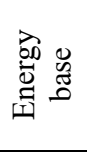 } & $\begin{array}{l}\text { Energy technology complexes are characterized by high cost and sophisticated } \\
\text { equipment, slowly adapting to the new realities of pricing }\end{array}$ \\
\hline & $\begin{array}{l}\text { The used energy equipment of foreign production is outdated, lags behind the } \\
\text { modern world level of development }\end{array}$ \\
\hline \multirow[b]{2}{*}{ 总 } & $\begin{array}{l}\text { Sugar production is one of the most traumatic types of food production; almost } \\
\text { all blue-collar occupations are classified as hazardous occupations }\end{array}$ \\
\hline & $\begin{array}{l}\text { The existing system of labor relations does not stimulate the employer to } \\
\text { improve the working conditions of the personnel, since the measures for their } \\
\text { implementation require significant financial costs in accordance with state } \\
\text { regulations }\end{array}$ \\
\hline \multirow{2}{*}{ 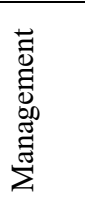 } & $\begin{array}{l}\text { Insufficient use of information systems due to the lack of a mathematical } \\
\text { description of objects and basic processes }\end{array}$ \\
\hline & $\begin{array}{l}\text { Methods and tools of functional management are used in the management of } \\
\text { sugar production; the benefits of process management focused on business } \\
\text { processes are practically not realized }\end{array}$ \\
\hline
\end{tabular}

The factors considered directly or indirectly determine the possibilities for the development of processing companies in the current crisis-market space, which is accompanied by an increase in the influence of destabilizing factors and necessitates an appropriate response. The methods and management tools used in sugar production organizations in most cases demonstrate an imbalance of business interests, underestimation of the possibilities for the expedient development of economic factors that contribute to the protection of competitive advantages and the harmonization of business relations [4]. As a result, it is expedient to switch to systemic management of economic factors of economic activity of processing organizations, using adequate management tools to neutralize or weaken the in-fluence of factors that inhibit or impede the development process.

\section{Materials and methods}

It is advisable to assess the impact of natural, production and economic indicators that quantitatively and qualitatively characterize the causes; it is advisable to carry out based on a structural-logical block diagram, which makes it possible to establish the presence and direction of connections not only between the factors themselves, but also between them and the effective indicator. In fig. 1 shows the key factors that generate (mainly) production risks, as well as their impact on the specific profit (tons of sugar). Thus, the systematization of economic factors allows for a deeper study of their interrelationships and direction of impact in the formation of the value of the effective indicator, which is of no small importance at the next stages of assessing the possibilities of conjugation of interests of participants in sugar production, especially at the stage of modelling the vector of dynamics of the studied indicators [5].

At the theoretical level, the production potential can be formalized as follows:

$$
P=(k, f, R)
$$

where $P$ - production potential of organization; $R$ - resources of organization; $f$ - resource organization level; $k$ - level of realization of untapped opportunities.

The key factor in the conjugation of business interests is the reason that directly or indirectly forms the level of organization of resources and untapped opportunities of resource potential: 


$$
f=\left(K_{f},\left\{\begin{array}{c}
k \\
P_{t e c h} \\
P_{m} \\
P_{l a b}
\end{array}\right\}\right)
$$

where $K_{f}$ - the key factor in the conjugation of business interests; $P_{\text {tech }}-$ technical component; $P_{m}$ - material component; $P_{l a b}$ - labour component.

For sugar factories that use sugar beets for processing, the most significant and influential are situations, phenomena, events related not so much to the external and internal, but to the conjugate environment in which the business interests of the parties are coupled and under the influence of the factors of which there is an increase and accelerating the bi-directional synergy effect. It is possible to assess the sources and causes of the available opportunities in the business environment in terms of the characteristics of the influence of individual factors on the level of economic activity. As factors that are particularly important for sugar production, the factors that arise and act mainly in a conjugate environment are identified and substantiated - these are the losses of beet raw materials during storage, transportation, and sugar during storage and processing. To assess the influence of the conjugate environment on the economic activity of sugar factories processing sugar beets, it is proposed to use the calculated coefficient of conjugation of business processes (coefficient of the conjugate environment influence), taking into account the total losses of sugar with beets during storage and transportation and sugar in production [6]:

$$
K_{c}=\left(1-\frac{L_{s}}{100}\right) \cdot\left(1-\frac{L_{s s u g}}{100}\right) \cdot\left(1-\frac{L_{p r}}{100}\right),
$$

where $L_{s}$ - losses of beets during storage and transportation, as a percentage of harvested beets; $L_{s}$ sug - loss of sugar during storage, as a percentage of harvested beets; $L_{p r}$ - sugar losses in production, including sugar content in molasses, as a percentage of harvested beets.

In other words, from an economic point of view, the value of the conjugation coefficient $\left(K_{c}\right)$, always less than 1 is interpreted as follows: $K_{c} \rightarrow 1$, but $K_{c} \neq 1$. The closer $K_{c}$ is to one, the less the influence of the associated environment, and the more opportunities for the organization of the sugar industry to increase profitability and develop economic activity.

When assessing the level of conjugation of interests, it is also necessary to take into account the specifics of this or that business process (groups of business processes). In particular, we will consider the influence of such factors as losses of beets and sugar during storage and transportation on the specific profit (per ton of sugar) and sales profitability, taking into account the following assumptions:

- natural and climatic conditions in a particular region differ from those in other regions, that is, a poor harvest of beets and their sugar content in a particular region does not have a significant effect on the market price of selling sugar beets, that is, on the amount of material costs of a sugar refinery;

- sugar factories cannot have a significant impact on the loss of beets during storage and transpor-tation by means of additional costs in extreme conditions: for example, high temperatures, excessive precipitation during harvesting. 


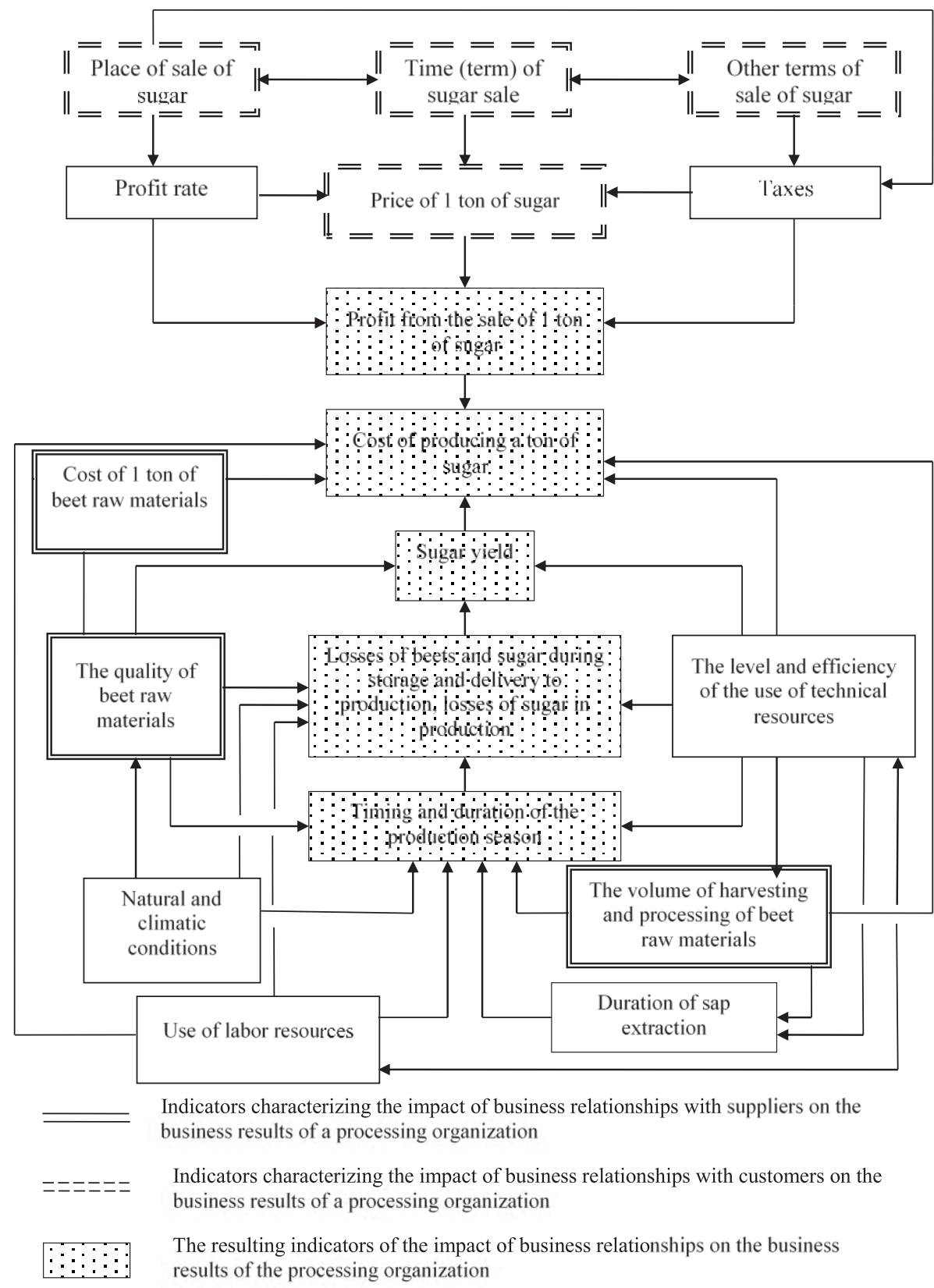

Fig. 1. Influence of key factors in the development of business relations on the results of economic activity of sugar processing organizations.

In this regard, a certain value for predicting and preventing (or reducing) risks is the development of a model for finding functional dependences of the specific profit (per ton of sugar) on the level of dynamics of conjugation of business interests of the participants in sugar production. Here is an algorithm for modeling this process [7].

$$
P=P r-C_{p r},
$$


where $P$ - profit per ton, rub., $P r$ - selling price of 1 ton of sugar beet, rubles / ton, $C_{p r}-$ cost price of $1 \mathrm{t}$, rubles / $\mathrm{t}$.

After purchasing the harvested sugar beet material costs (costs for beet raw materials) $\mathrm{MC}=$ const and do not depend on the amount of beets that will be processed. Therefore

$$
C_{p r}=C_{v a r . s p .}+\frac{C_{f}+C_{b e e t}}{A_{p}},
$$

where $C_{p r}$ - production cost, p.; $C_{f}$ - fixed costs, p .; $C_{\text {beet }}-$ the cost of harvested beet raw materials; $C_{\text {var.sp. }}-$ specific variable costs (minus the cost of beet raw materials), rubles / $t$; $A_{p}-$ the amount of sugar produced, t.

$$
A_{p}=A_{h} \cdot\left(1-L_{s t}\right) \cdot Y l d
$$

where $A_{h}$ - the amount of harvested sugar beet, $\mathrm{t}$; $L_{s t}$ - losses of beets during storage and transportation, units; Yld - sugar yield, units

Thus, we get:

$$
P=P r-C_{\text {var } . s p .}-\frac{C_{f}+C_{b e e t}}{A_{h} \cdot\left(1-L_{s t}\right) \cdot Y l d} .
$$

After the completion of the process of harvesting beet raw material, the sugar content of the beet on acceptance can be conditionally considered unchanged, in turn, the results of production activities begin to be influenced by factors of the conjugate environment, including sugar loss.

Potential change in profit:

$$
\begin{gathered}
\Delta P=\frac{C_{f}+C_{\text {beet }}}{A_{h} \times S u g} \times \frac{\Delta C_{C}+C_{C 1}-C_{C 1}}{C_{C 1} \times\left(\Delta C_{C}+C_{C 1}\right)} ; \\
\Delta P=\frac{C_{f}+C_{\text {beet }}}{A_{h} \times S u g} \times \frac{\Delta C_{C}}{C_{C 1} \times\left(\Delta C_{C}+C_{C 1}\right)} .
\end{gathered}
$$

If the planning goal is to determine the impact of both the external (in terms of interaction with suppliers) and the associated business environment on changes in income and profitability, then the sugar content and the cost of beet raw materials should be used as variables, taking into account its sugar content [8].

\section{Results and discussion}

For the correct performance of the reference comparison based on the values of the coupling coefficient, the following assumptions were used, which are acceptable for the modern development of sugar production technology in Russia on the example of a sugar plant with a production capacity of sugar beet processing $3000 \mathrm{t} /$ day $[9,10,11]$ :

- loss of sugar beet during storage and delivery to production $-4.6 \%$;

- loss of sugar during storage $-0.5 \%$; 
- $\quad$ sugar losses in production, including sugar content in molasses $-2.72 \%$.

The calculated baseline level of the conjugation coefficient was 0.923 units. Thus, for the case under consideration, the level of profit dynamics per ton of sugar produced is described by the following functional relationship:

$$
\begin{gathered}
\Delta P=(70593+882414) /(294138 * 17.01 / 100) * C_{c} /\left(0.923\left(C_{c}+0.923\right)\right. \\
\Delta P=20.6366 * \Delta C_{c} /\left(\Delta C_{c}+0,923\right) .
\end{gathered}
$$

Perceiving business relations as one of the main factors of economic activity, we made an assumption about the possible operation of the "law of diminishing returns" in the context of the categories under consideration, which manifests itself in the different-sized dynamics of the resulting indicator (profitability of sales) with an increase / decrease conjugation coefficient and unchanged values of other indicators [12,13]:

- the volume of harvested beets - 294138 tons,

- sugar content of sugar beet on acceptance - $17.01 \%$;

- purchase price of sugar beet - 3000 rub./ton (excluding VAT);

- the amount of fixed costs - 70593 thousand rubles;

- the sum of other variable costs (except for raw materials costs) - 223545 thousand rubles;

- total costs (raw material costs + fixed costs + other variable costs) - 1176552 thousand rubles;

- sugar sales price - 35000 rub./ton (excluding VAT)

For the purpose of the study, a step was adopted for changing the values of the coupling co-efficient $\pm 0.5 \%$ (in the range of $0.873-0.979$ units), which has a direct effect on the volume of sugar production and sales (tables 2-4). In this case, it is not of fundamental importance that of the indicators and to what extent had a positive / negative effect on the change in the conjugation coefficient $[14,15]$.

Table 2. Influence of the level of business relationships with suppliers on profit and sales profitability.

\begin{tabular}{|c|c|c|c|c|c|}
\hline $\begin{array}{c}\text { Coupling } \\
\text { coefficient, } \\
\text { units }\end{array}$ & $\begin{array}{c}\text { The amount } \\
\text { of sugar } \\
\text { produced, t. }\end{array}$ & $\begin{array}{c}\text { Proceeds } \\
\text { from the } \\
\text { sale of } \\
\text { sugar, } \\
\text { thousand } \\
\text { rubles }\end{array}$ & $\begin{array}{c}\text { Total costs, } \\
\text { thousand } \\
\text { rubles }\end{array}$ & $\begin{array}{c}\text { Profit from } \\
\text { the sale of } \\
\text { sugar, } \\
\text { thousand } \\
\text { rubles }\end{array}$ & profitability, \% \\
\hline 0.979 & 48973 & 1714054 & 1176552 & 537502 & 31.36 \\
\hline 0.974 & 48742 & 1705968 & 1176552 & 529416 & 31.03 \\
\hline 0.970 & 48511 & 1697883 & 1176552 & 521331 & 30.70 \\
\hline 0.965 & 48280 & 1689798 & 1176552 & 513246 & 30.37 \\
\hline 0.960 & 48049 & 1681713 & 1176552 & 505161 & 30.04 \\
\hline 0.956 & 47818 & 1673628 & 1176552 & 497076 & 29.70 \\
\hline 0.951 & 47587 & 1665543 & 1176552 & 488991 & 29.36 \\
\hline 0.946 & 47356 & 1657457 & 1176552 & 480905 & 29.01 \\
\hline 0.942 & 47125 & 1649372 & 1176552 & 472820 & 28.67 \\
\hline 0.937 & 46894 & 1641287 & 1176552 & 464735 & 28.32 \\
\hline 0.933 & 46663 & 1633202 & 1176552 & 456650 & 27.96 \\
\hline 0.928 & 46432 & 1625117 & 1176552 & 448565 & 27.60 \\
\hline $\mathbf{0 . 9 2 3}$ & 46201 & 1617032 & 1176552 & 440480 & 27.24 \\
\hline 0.919 & 45970 & 1608946 & 1176552 & 432394 & 26.87 \\
\hline 0.914 & 45739 & 1600861 & 1176552 & 424309 & 26.51 \\
\hline 0.910 & 45508 & 1592776 & 1176552 & 416224 & 26.13 \\
\hline 0.905 & 45277 & 1584691 & 1176552 & 408139 & 25.76 \\
\hline
\end{tabular}




\begin{tabular}{|l|l|l|l|l|l|}
\hline 0.900 & 45046 & 1576606 & 1176552 & 400054 & 25.37 \\
\hline 0.896 & 44815 & 1568521 & 1176552 & 391969 & 24.99 \\
\hline 0.891 & 44584 & 1560436 & 1176552 & 383884 & 24.60 \\
\hline 0.886 & 44353 & 1552350 & 1176552 & 375798 & 24.21 \\
\hline 0.882 & 44122 & 1544265 & 1176552 & 367713 & 23.81 \\
\hline 0.877 & 43891 & 1536180 & 1176552 & 359628 & 23.41 \\
\hline 0.873 & 43660 & 1528095 & 1176552 & 351543 & 23.01 \\
\hline 0.868 & 43429 & 1520010 & 1176552 & 343458 & 22.60 \\
\hline
\end{tabular}

Table 3. Influence of the level of business relations with suppliers on specific indicators of economic activity.

\begin{tabular}{|c|c|c|c|c|}
\hline $\begin{array}{c}\text { Coupling } \\
\text { coefficient, } \\
\text { units }\end{array}$ & $\begin{array}{c}\text { Material costs } \\
\text { (beet raw } \\
\text { materials) per ton } \\
\text { of sugar, r. }\end{array}$ & $\begin{array}{c}\text { Fixed costs per } \\
\text { ton of sugar, r. }\end{array}$ & $\begin{array}{c}\text { Total costs per } \\
\text { ton of sugar, r. }\end{array}$ & $\begin{array}{c}\text { Profit per ton } \\
\text { of sugar, } \text {. }\end{array}$ \\
\hline 0.979 & 18018 & 1441 & 24025 & 15540 \\
\hline 0.974 & 18104 & 1448 & 24138 & 15448 \\
\hline 0.970 & 18190 & 1455 & 24253 & 15355 \\
\hline 0.965 & 18277 & 1462 & 24369 & 15261 \\
\hline 0.960 & 18365 & 1469 & 24487 & 15166 \\
\hline 0.956 & 18454 & 1476 & 24605 & 15070 \\
\hline 0.951 & 18543 & 1483 & 24724 & 14973 \\
\hline 0.946 & 18634 & 1491 & 24845 & 14876 \\
\hline 0.942 & 18725 & 1498 & 24967 & 14777 \\
\hline 0.937 & 18817 & 1505 & 25090 & 14677 \\
\hline 0.933 & 18910 & 1513 & 25214 & 14577 \\
\hline 0.928 & 19004 & 1520 & 25339 & 14475 \\
\hline $\mathbf{0 . 9 2 3}$ & 19099 & 1528 & 25466 & 14373 \\
\hline 0.919 & 19195 & 1536 & 25594 & 14269 \\
\hline 0.914 & 19292 & 1543 & 25723 & 14164 \\
\hline 0.910 & 19390 & 1551 & 25854 & 14058 \\
\hline 0.905 & 19489 & 1559 & 25986 & 13952 \\
\hline 0.900 & 19589 & 1567 & 26119 & 13844 \\
\hline 0.896 & 19690 & 1575 & 26254 & 13735 \\
\hline 0.891 & 19792 & 1583 & 26390 & 13624 \\
\hline 0.886 & 19895 & 1592 & 26527 & 13513 \\
\hline 0.882 & 19999 & 1600 & 26666 & 13401 \\
\hline 0.877 & 20105 & 1608 & 26806 & 13287 \\
\hline 0.873 & 20211 & 1617 & 26948 & 13172 \\
\hline 0.868 & 20319 & 1625 & 27091 & 13056 \\
\hline & & & & \\
\hline
\end{tabular}

Table 4. Assessment of deviations of indicator values from the baseline.

\begin{tabular}{|c|c|c|c|c|c|}
\hline $\begin{array}{c}\text { Coupling } \\
\text { coefficient, } \\
\text { units }\end{array}$ & $\begin{array}{c}\text { Deviation } \\
\text { of the } \\
\text { conjugation } \\
\text { coefficient, } \\
\text { units }\end{array}$ & $\begin{array}{c}\text { Increase in the } \\
\text { coefficient of } \\
\text { conjugation,\% }\end{array}$ & $\begin{array}{c}\text { Profit } \\
\text { deviation, } \\
\text { thousand } \\
\text { rubles }\end{array}$ & $\begin{array}{c}\text { Deviation in } \\
\text { profits per } \\
\text { ton of sugar, } \\
\text { rub/t }\end{array}$ & $\begin{array}{c}\text { Deviation of } \\
\text { sales } \\
\text { profitability, } \\
\text { pn. }\end{array}$ \\
\hline 0.979 & 0.055 & 6.00 & 97022 & 1168 & 4.12 \\
\hline 0.974 & 0.051 & 5.50 & 88937 & 1075 & 3.79 \\
\hline 0.970 & 0.046 & 5.00 & 80852 & 982 & 3.46 \\
\hline 0.965 & 0.042 & 4.50 & 72766 & 888 & 3.13 \\
\hline 0.960 & 0.037 & 4.00 & 64681 & 793 & 2.80 \\
\hline 0.956 & 0.032 & 3.50 & 56596 & 698 & 2.46 \\
\hline 0.951 & 0.028 & 3.00 & 48511 & 601 & 2.12 \\
\hline
\end{tabular}




\begin{tabular}{|l|c|c|c|c|c|}
\hline 0.946 & 0.023 & 2.50 & 40426 & 503 & 1.77 \\
\hline 0.942 & 0.018 & 2.00 & 32341 & 404 & 1.43 \\
\hline 0.937 & 0.04 & 1.50 & 24255 & 305 & 1.08 \\
\hline 0.933 & 0.009 & 1.00 & 16170 & 204 & 0.72 \\
\hline 0.928 & 0.005 & 0.50 & 8085 & 103 & 0.36 \\
\hline $\mathbf{0 . 9 2 3}$ & 0 & 0 & 0 & 0 & 0.00 \\
\hline 0.919 & -0.005 & -0.50 & -8085 & -104 & -0.37 \\
\hline 0.914 & -0.009 & -1.00 & -16170 & -208 & -0.73 \\
\hline 0.910 & -0.014 & -1.50 & -24255 & -314 & -1.11 \\
\hline 0.905 & -0.018 & -2.00 & -32341 & -421 & -1.48 \\
\hline 0.900 & -0.023 & -2.50 & -40426 & -529 & -1.87 \\
\hline 0.896 & -0.028 & -3.00 & -48511 & -638 & -2.25 \\
\hline 0.891 & -0.032 & -3.50 & -56596 & -748 & -2.64 \\
\hline 0.886 & -0.037 & -4.00 & -64681 & -859 & -3.03 \\
\hline 0.882 & -0.042 & -4.50 & -72766 & -972 & -3.43 \\
\hline 0.877 & -0.046 & -5.00 & -80852 & -1086 & -3.83 \\
\hline 0.873 & -0.051 & -5.50 & -88937 & -1201 & -4.23 \\
\hline 0.868 & -0.055 & -6.00 & -97022 & -1317 & -4.64 \\
\hline
\end{tabular}

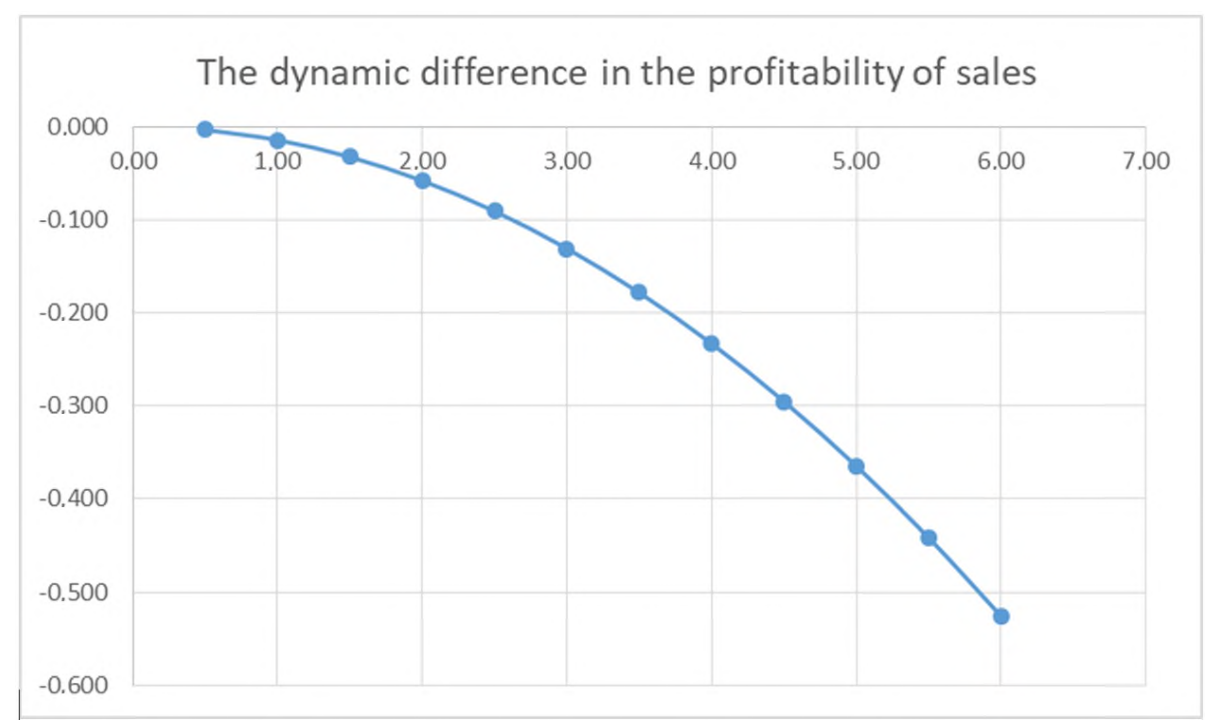

Fig. 2. The dynamic difference in the profitability of sales with equal, but oppositely directed deviations of the values of the coupling coefficient from the base level.

Let us evaluate the results of the situations we have modeled, depending on the change in the coupling coefficient, which takes into account the total losses of beets and sugar during storage, delivery to production and in production [16-17]. Reducing losses to a level, for example, sugar losses during storage - $0.42 \%$, sugar losses in production, incl. content in molasses $-0.85 \%$, losses of beets during storage and delivery to production $-1.18 \%$ led to an increase in the coupling coefficient by 0.055 units (an increase of $6 \%$ ), which in turn affected the specific profit, increasing it by 1168 rubles / $t$ (an increase of $8.12 \%$ ) (table 5) [18]. Against this background, the increase in profitability amounted to $4.12 \mathrm{pn}$, which ensured an increase in the mass of profit by 97.022 million rubles [19]. An increase in losses, and as a con-sequence, a decrease in the level of the conjugation coefficient by the same percentage points, led to the same reduction in the mass of profit by 97.022 million rubles (decrease $-9.16 \%$ ) and a decrease in profitability by $4.64 \mathrm{pn}$. Thus, we can conclude that the deviation of the coupling coefficient from the baseline in the range $[-6 \% ;+6 \%]$ has 
a different-sized impact on the profitability of business activities in two areas of dynamics [-4.64 pn; 4.12pn. [20]. The clearly identified dynamic differences demonstrating the prevailing influence of the negative vector of deviations are shown in Figure 2.

\section{Conclusion}

Due to the constantly changing conditions for the functioning of organizations under the influence of a dynamic business environment, as well as the laboriousness of drawing up flexible budgets with a lot of indicators that are not used for evaluation and analysis, many authors express an opinion about refusing to draw up flexible budgets in favor of assessing key impact indicators, which characterizes the proposed approach as relevant for the purpose of predicting the level of profitability and assessing business activities.

The obtained ratios allow us to state the presence of certain dynamic imbalances in the change in the level of profitability, the manifestation of which increases with the growth of the range of deviations of the conjugation coefficient from the base level. The perception of the base level of the values of the assessed indicators and indicators forms a certain parametric model that fragmentarily characterizes the system of harmonious business relations between producers and processors of beet raw materials. With an equal change in the coefficient of the conjugate environment, a higher rate of decrease in the specific weight of profit (per ton of sugar) is observed in comparison with an increase in this indicator, therefore, the management of related factors affecting the specific profit (losses of beets and sugar during storage, transportation and in production), is of key importance in the process of generating in-comes of processing organizations of sugar production and characterizes the need to reduce these losses in order to optimize the profitability of economic activity.

In the course of the evaluation and analytical procedures, it was found that the resulting indicator (profit) and indicator (profitability) are not significantly influenced by the composition and structure of costs, which confirms the conditional isolation of the factors of the associated environment and their specific impact on the results of economic detail processing organizations of sugar production. In addition, this feature, as well as the almost single-product nomenclature of sugar production, makes it possible to conclude that the revealed proportions (disparities) are comparable for organizations with a greater or lesser production capacity, as a rule, with a significantly different mass of fixed costs. At the same time, if one of the objects of appraisal procedures is marginal income or break-even production volume, then the composition and structure of production costs will be essential for obtaining correct analytical results and conclusions.

The revealed dependence of the resulting indicators is characteristic not only for sugar produc-tion, but also for other sectors of the agro-industrial complex, including agriculture, and should be tak-en into account by managers when planning production activities and budgeting.

\section{References}

1. E. Voskresenskaya, L. Vorona-Slivinskaya, L. Achba, Digital economy: theoretical and legal enforcement issues in terms of regional aspect, Environmental and Resource Economics, 164, 09016 (2020) https://doi.org/10.1051/e3sconf/202016409016

2. A. E. Castillo, G. V. Pacheco, L. Hernández-Fernández, E. N. Manotas, J. Silva, Factorial Analysis in the Intellectual capital's dimensions on micro, small, and medium-sized export enterprises, Procedia Computer Science, 160, 567-572 (2019) https://doi.org/10.1016/j.procs.2019.11.046L. 
3. M. Prys, J. Krysińska, P. Janaszkiewicz, P. Winiecki, P. Różewski, System analysis of human capital for information system development, Procedia Computer Science, 126, 1197-1205 (2018) https://doi.org/10.1016/j.procs.2018.08.060

4. S. B. Holland, Firm investment in human health capital, Journal of Corporate Finance, 46, 374-390 (2017) https://doi.org/10.1016/j.jcorpfin.2017.08.003

5. B. Jacobs, Real options and human capital investment, Labour Economics, 14, 913-925 (2007) https://doi.org/10.1016/j.labeco.2007.06.008

6. C. Christiansen, J. Joensen, H. Nielsen, The risk-return trade-off in human capital investment, Labour Economics, 14, 971-986 (2007) https://doi.org/10.1016/j.labeco.2007.06.001

7. R. Almeida, P. Carneiro, The return to firm investments in human capital, Labour Economics, 16, 97-106 (2009) https://doi.org/10.1016/j.labeco.2008.06.002V

8. V. Plotnikov, O. Pirogova, Key Competencies as an Enterprise Value Management Tool, IBIMA 2018, 1716-1721 (2018)

9. I. Aleksandrov, M. Fedorova, Development of e-commerce, transport and logistics in rural Russia: Attitudes and obstacles, E3S Web of Conferences (2020) https://doi.org/10.1051/e3sconf/202016407008

10. E. Bykova, T. Baltyzhakova, Y. Volkova, Classification of inhabited localities by the level of development of individual residential land market Bulletin of the Tomsk Polytechnic University, Geo Assets Engineering, 329, 7, 17 - 30 (2018)

11. A. Ajupov, A. Sherstobitova, S. Syrotiuk, A. Karataev, International Science Conference SPbWOSCE-2018 "Business Technologies for Sustainable Urban Development” 110, 02040 (2019) DOI 10.1051/e3sconf/201911002040

12. A. Sergeev, L. Akhmetshina, K. Grabovyy, International Science Conference SPbWOSCE-2018 “Business Technologies for Sustainable Urban Development” 110, 02153 (2019) DOI 10.1051/e3sconf/201911002153

13. O. Kravchenko, M. Leshchenko, D. Marushchak, Y. Vdovychenko, S. Boguslavska, The 8th International Conference on Monitoring, Modeling \& Management of Emergent Economy 65, 07004, (2019) DOI 10.1051/shsconf/20196507004

14. O. Pirogova, E. Gorin, V. Plotnikov, The algorithms for the environmental finance based on adjusted present value models, E3S Web of Conferences, 91, 08021 (2019)

15. J. Yoshida, The economic depreciation of real estate: Cross-sectional variations and their return implications, Pacific-Basin Finance Journal, 61, 101290 (2020) https://doi.org/10.1016/j.pacfin.2020.101290

16. E. Fang, W. R. Palmatier, J.-B. E. Steenkamp, Effect of Service Transition Strategy on Firm Value, Journal of Marketing 72, 1-14 (2008) https://doi.org/10.1509/jmkg.72.5.1

17. M. M. Hasan, Corporate life cycle, organizational financial resources and corporate social responsibility, Journal of Contemporary Accounting \& Economics, 13, 20-36 (2017) DOI: 10.1016/j.jcae.2017.01.002

18. K. M. Bakarich, M. Hossain, J. Weintrop, Different time, different tone: Company life cycle, Journal of Contemporary Accounting and Economics, 15(1), 69-86 (2019) https://doi.org/10.1016/j.jcae.2018.12.002

19. O. Pirogova, V. Plotnikov, Z. Popovic, et al. The Multi-level Model of the Service Enterprises Human Capital Value. (Eds.): TransSiberia 2019, AISC 1116, 738-747 (2020) https://doi.org/10.1007/978-3-030-37919-3_73M.

20. A. A. Salisu, I. D. Raheem, U. B. Ndako, The inflation hedging properties of gold, stocks and real estate: A comparative analysis, Resources Policy 66, 101605 (2020) https://doi.org/10.1016/j.resourpol.2020.101605 